\title{
Age and Gender Differences in Nutritional Status of School Children According to WHO, CDC and IOTF References: A Statewide Study from Montenegro
}

\author{
Rajko Milasinovic', Danilo Bojanic', Aleksandar Cvorovic ${ }^{2}$ and Filip Kukic ${ }^{2}$ \\ 'University of Montenegro, Faculty for Sports and Physical Education, Niksic, Montenegro, ${ }^{2}$ Abu Dhabi Police, Police Sports Education Center, Abu \\ Dhabi, United Arab Emirates
}

\begin{abstract}
Nutritional status of school children has been discussed over the past decade, focusing on timely and adequate response that can positively affect the reduction of the health risks of overweight, obesity, and malnutrition. Thus, the aim of this study was to evaluate a nutritional status of healthy children from Montenegro according to three most common worldwide references. The sample of 1480 healthy school children was consisted of girls $(\mathrm{N}=733)$, mean age $=10.98 \pm 1.38$ years, mean body height $\mathrm{BH}=152.25 \pm 10.22 \mathrm{~cm}$, and mean body mass $\mathrm{BM}=43.93 \pm 11.51$ $\mathrm{kg}$, and boys $(\mathrm{N}=747)$, mean age $=10.95 \pm 1.41$, mean $\mathrm{BH}=153.26 \pm 11.18 \mathrm{~cm}$, and mean $\mathrm{BM}=46.16 \pm 13.21 \mathrm{~kg} . \mathrm{A}$ nutritional status was defined by body mass index (BMI) and compared to the references developed by World Health Organization (WHO), Centers for Disease Control and Prevention (CDC) and International Obesity Task Force (IOTF). Prevalence differences relative to age and gender were analyzed as well. Results suggest that IOTF is the most appropriate method in absence of national references for growth and nutritional status. Furthermore, increase in prevalence of overweight and obese in boys was relatively high considering the time frame (5 years), while increase in girls was somewhat smaller, but nevertheless present. In total, every third (WHO) or every fourth (CDC and IOTF) child in Montenegro aged 9-13 years is either overweight or obese.
\end{abstract}

Key words: body mass index, prevalence, obesity, overweight, underweight

\section{Introduction}

According to World Health Organization (WHO), increasing trend of obesity among children and preadolescents is one of the leading health problems (WHO, 1995). The obesity can be caused by many factors such as genetics, socio-cultural or environmental factors. However, in majority of cases the obesity is caused by a nutritional disbalance due to higher calorie intake than can be spent during the day, which leads to storing the excess energy as fat tissue (Lukaski, 2017). Since the changes in nutritional status can be noticed in quickly accessible body composition characteristics such as body mass $(\mathrm{BM})$, body height $(\mathrm{BH})$ or waist circumference (WC), the analysis of body composition became a standard tool in epidemiological and statewide studies (WHO, 2000).

In this type of research morphological measurements represent a basis for obtaining data (Bjelica, 2010). The screening of nutritional status in a pediatric population is very challenging process because of the fast growth and physical development, which characterizes childhood, preadolescence and adolescence (Cole, Flegal, Nicholls, \& Jackson, 2007; Wang \& Chen, 2012). Therefore, a precise, valid and reliable method should be used for these purposes. Assessment of anthropometric measurements is standardized method, commonly to estimate nutritional status of body composition, and

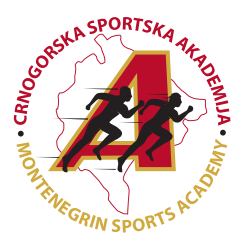

Correspondence:

R. Milasinovic

University of Montenegro, Faculty for Sports and Physical Education, Niksic, Montenegro

E-mail: rajko.m@ucg.ac.me 
globally used references are WHO, Centers for Disease Control and Prevention (CDC) and International Obesity Task Force (IOTF), (de Onis et al., 2007; Kuczmarski et al., 2002; Cole et al., 2007). In addition to the above references, several countries have developed national references to growth and development on nationally significant samples of their populations using similar methodology (Tambalis et al., 2015), but this is not case in Montenegro.

Various types of adaptation of human beings have, led to a change in the phenotype, which changed genotypes over generations (Bjelica, 2006). This has led to the development of different individuals within a community of living beings (Bjelica, 2006). Although a modern way of life brings up many advantages providing better and easier functioning of people, it is also evident that a negative adaptation such as nutrition transition and reduction of physical activity occurred as well (Ng et al., 2014). Especially sensitive periods that can be influenced by these changes are childhood and preadolescence whereby obese children and preadolescents are more likely to be obese adults ( $\mathrm{Ng}$ et al., 2014). In contrast, increasing trend of underweight children can be noticed worldwide, which also can be a burden and lead to increased health risk (Tuan \& Nicklas, 2009; Popkin, 2006). In that regards, developing a national normative values of body composition characteristics for an early detection of nutritional status of children and preadolescents plays an important role in prevention of obesity.

There has been a lack of comprehensive researches related to nutritional status of children from Montenegro. Except from Martinovic et al. (2015) and Jaksic et al. (2017), next available data were from former Serbia and Montenegro from 2004. However, prevalence of overweight and obese children increased by one-third since then (Martinovic et al., 2015). A survey by the World Health Organization "European Childhood Obesity Surveillance Initiative-COSI", conducted by 4,000 children in Montenegro, showed the worrying incidence of overweight and obesity in Montenegro (Institute of Public Health, 2016). In that regards, the main goal of this study was to evaluate current nutritional status in school children (9-13 yrs.) from Montenegro and to explore possible gender and age differences. Another objective was to compare the results with peers from the region and globally with studies that used similar methodology.

\section{Methods}

This study could be classified as a cross-sectional study design conducted on a stratified sample of school children from Montenegro aged 9-13 years. Children from three geographical regions (southern, central and northern) were included in the study and their nutritional status was evaluated and compared to three most common references: World Health Organization - WHO (de Onis et al., 2007), Centers for Disease Control and Prevention - CDC (Kuczmarski et al., 2002) and International Obesity Task Force - IOTF (Cole et al., 2007) and classified into four categories: Underweight, Normal, Overweight, and Obesity (Table 1)

Table 1. Cut-off values for used references for purpose of evaluation of nutritional status

\begin{tabular}{|c|c|c|c|c|}
\hline References & Underweight & Normal & Overweight & Obesity \\
\hline WHO & $\begin{array}{l}\text { BMI-for-age } \\
\text { Z-score }<-2\end{array}$ & $\begin{array}{l}\text { BMI-for-age } \\
\text { Z-score-2 to } 1\end{array}$ & $\begin{array}{l}\text { BMI-for-age } \\
\text { Z-score }>1\end{array}$ & $\begin{array}{l}\text { BMI-for-age } \\
\text { Z-score }>2\end{array}$ \\
\hline$C D C$ & $\begin{array}{c}\text { BMl }< \\
5^{\text {th }} \text { percentile }\end{array}$ & $\begin{array}{c}\mathrm{BMI} \\
\geq 5^{\text {th }} \text { to }<85^{\text {th }} \text { percentile }\end{array}$ & $\begin{array}{c}\mathrm{BMI} \geq \\
85^{\text {th }} \text { percentile }\end{array}$ & $\begin{array}{c}\mathrm{BMI} \geq \\
95^{\text {th }} \text { percentile }\end{array}$ \\
\hline IOTF & $\begin{array}{c}\mathrm{BMI}<18.5 \\
\text { at age } 18\end{array}$ & $\begin{array}{c}\text { BMI } 18.5 \text { to }<25 \\
\text { at age } 18\end{array}$ & $\begin{array}{c}\text { BMI } 25 \text { to }<30 \\
\text { at age } 18\end{array}$ & $\begin{array}{c}\mathrm{BMI} \geq 30 \\
\text { at age } 18\end{array}$ \\
\hline
\end{tabular}

\section{Subjects}

The sample of 1480 healthy school children were consisted of girls $(\mathrm{N}=733)$ and boys $(\mathrm{N}=747)$. The main characteristics for the girls were: mean age $=10.98 \pm 1.38$ years, mean body height $\mathrm{BH}=152.25 \pm 10.22 \mathrm{~cm}$, and mean body mass $\mathrm{BM}=43.93 \pm 11.51 \mathrm{~kg}$; and for the boys: mean age $=10.95 \pm 1.41$, mean $\mathrm{BH}=153.26 \pm 11.18 \mathrm{~cm}$, and mean $\mathrm{BM}=46.16 \pm 13.21 \mathrm{~kg}$. All measurements were conducted on a national level including southern, central and northern region of the country, during the school year 2017/18. School principals, parents and children were informed about the purpose of the measurement and children were measured only if everybody signed the informed consent prior the measurements were taken. Children with medical conditions (such as Down syndrome, Marfan syndrome, serious hormonal disorder, diseases that affect loss of muscle mass, reduction in bone density) were measured but excluded from the sample of this study. The research was carried out in accordance with the conditions of declaration of Helsinki, recommendations guiding physicians in biomedical research involving human subjects (Christie, 2000).

\section{Measurement procedures}

Nutritional status was estimated based on body mass index (BMI), whereby the BMI was calculated by dividing BM in kilograms $(\mathrm{kg})$ with square of $\mathrm{BH}$ in meters $(\mathrm{m}), \mathrm{BMI}=\mathrm{BM} /$ $\mathrm{BH}^{2}$ and expressed in $\mathrm{kg} / \mathrm{m}^{2}$. Body height and body weight were measured using a SECA 220 (Seca GmbH \& Co. KG.) weighing and measuring scale with a telescopic measuring rod, with the precision of $0.1 \mathrm{~kg}$ and $0.1 \mathrm{~cm}$. All participants were dressed in shorts and T-shirt and during both measurements they were barefooted. Measurements were provided by trained and experienced staff from Faculty for Sport and Physical Education, University of Montenegro.

\section{Statistics}

The descriptive statistics for means (mean) and standard deviations $( \pm \mathrm{SD})$ for $\mathrm{BM}, \mathrm{BW}$ and $\mathrm{BMI}$ were calculated using a statistical package for social sciences (IBM, SPSS 20.0). The same software was used for independent sample T-test, with Leven's test for equality of variance, to identify possible differences between genders related to same age category with significance level set at $\mathrm{p}=0.05$. To test the differences between the age groups, the analysis of variance (one-way ANOVA) with Bonferroni post-hoc test was used, and significance level was set at $\mathrm{p}=0.05$. To calculate the BMI relative to age according to WHO and CDC, a Microsoft's Gowth-Z excel workbook with possibility of batch calculation (Canadian Pediatric Endocrine Group, 2018) was used. For calculation of estimated 
BMI according to IOTF references was LMS growth (version 2.77) used, through a Microsoft Excel add-in written using Excel 2000 with Visual Basic for Applications -VBA (Pan \& Cole, 2012). Both, Growth-Z and LMS growth for calculation were based on LMS method. This method summarizes the changing distribution by three curves representing skewness (L), median (M) and coefficient of variation (S), for details about the method see: Cole and Green (1992). Nutritional status was presented by percentages (\%), and related to different references (WHO, CDC and IOTF) and their recommended cut-off points.

\section{Results}

Basic descriptive data (mean and standard deviation) for $\mathrm{BH}, \mathrm{BM}$ and $\mathrm{BMI}$ classified by gender and age are presented in Table 2.

Table 2. Descriptive statistics for Girls and Boys relative to age

\begin{tabular}{ccccccccc}
\hline $\begin{array}{c}\text { Age } \\
\text { (years) }\end{array}$ & $\mathbf{N}$ & $\begin{array}{c}\text { BH }(\mathbf{c m}) \\
\text { Mean } \pm \text { SD }\end{array}$ & $\begin{array}{c}\text { BM }(\mathbf{k g}) \\
\text { Mean } \pm \text { SD }\end{array}$ & $\begin{array}{c}\text { BMI }\left(\mathbf{k g} / \mathbf{m}^{2}\right) \\
\text { Mean } \pm \text { SD }\end{array}$ & N & $\begin{array}{c}\text { BH }(\mathbf{c m}) \\
\text { Mean } \pm \text { SD }\end{array}$ & $\begin{array}{c}\text { Boys } \\
\text { BM }(\mathbf{k g})\end{array}$ & $\begin{array}{c}\text { BMI }\left(\mathbf{k g} / \mathbf{m}^{2}\right) \\
\text { Mean } \pm \text { SD }\end{array}$ \\
\hline 9 & 133 & $141.11 \pm 6.45$ & $34.70 \pm 7.83$ & $17.71 \pm 2.94$ & 148 & $142.85 \pm 6.05$ & $36.80 \pm 8.52$ & $17.91 \pm 3.33$ \\
10 & 164 & $146.83 \pm 7.15$ & $39.38 \pm 8.85$ & $18.11 \pm 2.96$ & 174 & $147.22 \pm 6.61$ & $41.17 \pm 10.21$ & $18.85 \pm 3.74$ \\
11 & 157 & $152.01 \pm 7.07$ & $42.15 \pm 8.61$ & $18.13 \pm 2.87$ & 135 & $151.66 \pm 6.67$ & $44.79 \pm 10.79$ & $19.32 \pm 3.74$ \\
12 & 139 & $158.99 \pm 6.58$ & $50.01 \pm 9.63$ & $19.74 \pm 3.43$ & 148 & $159.18 \pm 8.62$ & $51.79 \pm 12.89$ & $20.24 \pm 3.67$ \\
13 & 140 & $162.75 \pm 6.51$ & $53.98 \pm 11.13$ & $20.32 \pm 3.69$ & 142 & $166.83 \pm 8.12$ & $57.43 \pm 12.26$ & $20.49 \pm 3.47$ \\
Total & 733 & $152.25 \pm 10.22$ & $43.93 \pm 11.51$ & $18.70 \pm 3.37$ & 747 & $153.26 \pm 11.18$ & $46.16 \pm 13.21$ & $19.33 \pm 3.71$ \\
\hline
\end{tabular}

Independent samples T-test on a whole sample for BH did gnificantly higher BMI then girls $\left(\mathrm{md}=0.64 \mathrm{~kg} / \mathrm{m}^{2}, \mathrm{t}_{1469.44}=3.45\right.$, not show significance $\left(\mathrm{t}_{147.82}=1.81, \mathrm{p}=0.070\right)$, while boys were $\left.\mathrm{p}<0.001\right)$. The difference between the genders relative to age significantly heavier than girls by heaving $2.2 \mathrm{~kg}$ of mean diffe- $\quad$ showed fluctuation in results (Table 3 ). rence $(\mathrm{md})$ in $\mathrm{BM}\left(\mathrm{t}_{1457.69}=3.45, \mathrm{p}<0.001\right)$ and therefore had si-

Table 3. Independent samples T-test results for total gender differences and for same age differences for Girls and Boys related to BH, BM and BMI

\begin{tabular}{|c|c|c|c|c|c|}
\hline Age & Variable & $\mathbf{t}$ & $\begin{array}{l}\text { Degree of } \\
\text { freedom }\end{array}$ & Significance & $\begin{array}{c}\text { Mean difference } \\
\text { (Girls - Boys) }\end{array}$ \\
\hline \multirow{3}{*}{9} & $\mathrm{BH}$ & -2.335 & 279 & $0.020 *$ & $-1.74 \mathrm{~cm}$ \\
\hline & BM & -2.141 & 279 & $0.033^{*}$ & $-2.10 \mathrm{~kg}$ \\
\hline & BMI & -1.614 & 279 & 0.108 & $-0.62 \mathrm{~kg} / \mathrm{m}^{2}$ \\
\hline \multirow{3}{*}{10} & $\mathrm{BH}$ & -0.524 & 336 & 0.601 & $-0.39 \mathrm{~cm}$ \\
\hline & BM & -1.728 & 333.69 & 0.085 & $-1.80 \mathrm{~kg}$ \\
\hline & BMI & -2.008 & 326.16 & $0.045^{*}$ & $-0.74 \mathrm{~kg} / \mathrm{m}^{2}$ \\
\hline \multirow{3}{*}{11} & $\mathrm{BH}$ & 0.427 & 290 & 0.670 & $0.35 \mathrm{~cm}$ \\
\hline & BM & -2.281 & 255.32 & $0.023^{*}$ & $-2.64 \mathrm{~kg}$ \\
\hline & BMI & -2.999 & 249.08 & $0.003^{*}$ & $-1.19 \mathrm{~kg} / \mathrm{m}^{2}$ \\
\hline \multirow{3}{*}{12} & $\mathrm{BH}$ & -0.212 & 273.74 & 0.832 & $-0.19 \mathrm{~cm}$ \\
\hline & BM & -1.332 & 271.59 & 0.184 & $-1.78 \mathrm{~kg}$ \\
\hline & BMI & -1.185 & 285 & 0.237 & $-0.50 \mathrm{~kg} / \mathrm{m}^{2}$ \\
\hline \multirow{3}{*}{13} & $\mathrm{BH}$ & -4.662 & 268.77 & $0.001 *$ & $-4.08 \mathrm{~cm}$ \\
\hline & BM & -2.475 & 278.14 & $0.014^{*}$ & $-3.45 \mathrm{~kg}$ \\
\hline & $\mathrm{BMI}$ & -0.41 & 280 & 0.682 & $-0.18 \mathrm{~kg} / \mathrm{m}^{2}$ \\
\hline \multirow{3}{*}{ TOTAL } & $\mathrm{BH}$ & -1.81 & 1470.82 & 0.070 & $-1.01 \mathrm{~cm}$ \\
\hline & BM & -3.452 & 1457.69 & $0.001^{*}$ & $-2.23 \mathrm{~kg}$ \\
\hline & BMI & -3.453 & 1469.45 & $0.001 *$ & $-0.64 \mathrm{~kg} / \mathrm{m}^{2}$ \\
\hline
\end{tabular}

Legend: *significant difference at the 0.05 level

When compared within the group of 9 years of age, boys were heaving significantly higher $\mathrm{BH}\left(\mathrm{t}_{279}=2.34, \mathrm{p}=0.020\right.$, $\mathrm{md}=1.74 \mathrm{~cm})$ and $\mathrm{BM}\left(\mathrm{t}_{279}=2.14, \mathrm{p}=0.033, \mathrm{md}=2.10 \mathrm{~kg}\right)$ than girls, but without significant difference in case of BMI $\left(\mathrm{t}_{279}=1.61, \mathrm{p}=0.108, \mathrm{md}=0.62 \mathrm{~kg} / \mathrm{m}^{2}\right)$. In case of 10 -years group, there were no significant differences between genders in $\mathrm{BH}\left(\mathrm{t}_{336}=0.42, \mathrm{p}=0.678\right)$ and $\mathrm{BM}\left(\mathrm{t}_{333.69}=1.63, \mathrm{p}=0.103\right)$, but BMI was significantly higher in boys $\left(\mathrm{t}_{326.16}=2.01, \mathrm{p}=0.045\right.$, 
$\mathrm{md}=0.74 \mathrm{~kg} / \mathrm{m}^{2}$ ). Among the 11 years old children, there were no significant differences between boys and girls in $\mathrm{BH}\left(\mathrm{t}_{290}=0.43, \mathrm{p}=0.670\right)$, but boys had significantly higher $\mathrm{BM}\left(\mathrm{t}_{255.31} 2.281, \mathrm{p}=0.023, \mathrm{md}=2.64 \mathrm{~kg}\right)$ and BMI $\left(\mathrm{t}_{249.08=} 2.99\right.$ $\mathrm{p}=0.003, \mathrm{md}=1.19 \mathrm{~kg} / \mathrm{m}^{2}$ ). For 12 -year groups there were no significant differences in any variable $\mathrm{BH}\left(\mathrm{t}_{273.74}=0.21\right.$, $\mathrm{p}=0.832), \mathrm{BM} \quad\left(\mathrm{t}_{271.59}=1.33, \mathrm{p}=0.184\right)$ and $\operatorname{BMI}(\mathrm{t}=1.185$, $\mathrm{p}=0.237)$. However, for a 13 -year group significant diffe- rences occurred in two variables, whereby boys were having higher $\mathrm{BH}\left(\mathrm{t}_{268.77}=4.66, \mathrm{p}<0.001, \mathrm{md}=4.08 \mathrm{~cm}\right)$ and $\mathrm{BM}$ $\left(\mathrm{t}_{278.14}=2.47, \mathrm{p}=0.014, \mathrm{md}=3.45 \mathrm{~kg}\right)$ but without significant differences related to BMI $(\mathrm{t}=0.41, \mathrm{p}=0.682, \mathrm{md}=0.18 \mathrm{~kg} /$ $\mathrm{m}^{2}$ ).

The results of Bonferroni post-hoc test showed significant differences $(\mathrm{p}<0.05)$ between all age groups in girls for BH (Table 4).

Table 4. Multiple comparisons related to age within same gender (Bonferroni post-hoc test)

\begin{tabular}{|c|c|c|c|c|c|c|c|}
\hline \multicolumn{2}{|c|}{ Age group } & \multicolumn{3}{|c|}{$\begin{array}{l}\text { Mean difference (A-B) } \\
\text { Girls }\end{array}$} & \multicolumn{3}{|c|}{$\begin{array}{c}\text { Mean difference (A-B) } \\
\text { Boys }\end{array}$} \\
\hline $\mathbf{A}$ & B & BH & BM & BM1 & BH & BM & BM1 \\
\hline \multirow{4}{*}{9} & 10 & $-5.718^{*}$ & $-4.675^{*}$ & -0.82 & $-4.368 *$ & $-4.372 *$ & -0.94 \\
\hline & 11 & $-10.894 *$ & $-7.450 *$ & -0.839 & $-8.806^{*}$ & $-7.988 *$ & $-1.409^{*}$ \\
\hline & 12 & $-17.883 *$ & $-15.310^{*}$ & $-2.447^{*}$ & $-16.332 *$ & $-14.994 *$ & $-2.330^{*}$ \\
\hline & 13 & $-21.637^{*}$ & $-19.276^{*}$ & $-3.022 *$ & $-23.977^{*}$ & $-20.628^{*}$ & $-2.582 *$ \\
\hline \multirow{4}{*}{10} & 9 & $5.718^{*}$ & $4.675^{*}$ & 0.82 & $4.368^{*}$ & $4.372 *$ & 0.94 \\
\hline & 11 & $-5.177 *$ & -2.774 & -0.019 & $-4.438 *$ & $-3.616^{*}$ & -0.469 \\
\hline & 12 & $-12.165^{*}$ & $-10.635^{*}$ & $-1.627^{*}$ & $-11.964 *$ & $-10.622^{*}$ & $-1.391 *$ \\
\hline & 13 & $-15.920 *$ & $-14.601 *$ & $-2.202 *$ & $-19.609 *$ & $-16.256^{*}$ & $-1.642 *$ \\
\hline \multirow{4}{*}{11} & 9 & $10.894 *$ & $7.450 *$ & 0.839 & $8.806^{*}$ & $7.988^{*}$ & $1.409 *$ \\
\hline & 10 & $5.177^{*}$ & 2.774 & 0.019 & $4.438^{*}$ & $3.616^{*}$ & 0.469 \\
\hline & 12 & $-6.989 *$ & $-7.860 *$ & $-1.608^{*}$ & $-7.526^{*}$ & $-7.006^{*}$ & -0.922 \\
\hline & 13 & $-10.743 *$ & $-11.827 *$ & $-2.183 *$ & $-15.171 *$ & $-12.640 *$ & -1.173 \\
\hline \multirow{4}{*}{12} & 9 & $17.883^{*}$ & $15.310^{*}$ & $2.447 *$ & $16.332 *$ & $14.994 *$ & $2.330^{*}$ \\
\hline & 10 & $12.165^{*}$ & $10.635^{*}$ & $1.627^{*}$ & $11.964 *$ & $10.622 *$ & $1.391 *$ \\
\hline & 11 & $6.989 *$ & $7.860 *$ & $1.608^{*}$ & $7.526^{*}$ & $7.006^{*}$ & 0.922 \\
\hline & 13 & $-3.754 *$ & $-3.966^{*}$ & -0.575 & $-7.645^{*}$ & $-5.634 *$ & -0.252 \\
\hline \multirow{4}{*}{13} & 9 & $21.637^{*}$ & $19.276^{*}$ & $3.022 *$ & $23.977^{*}$ & $20.628^{*}$ & $2.582^{*}$ \\
\hline & 10 & $15.920 *$ & $14.601 *$ & $2.202 *$ & $19.609 *$ & $16.256^{*}$ & $1.642 *$ \\
\hline & 11 & $10.743^{*}$ & $11.827^{*}$ & $2.183^{*}$ & $15.171 *$ & $12.640 *$ & 1.173 \\
\hline & 12 & $3.754 *$ & $3.966^{*}$ & 0.575 & $7.645^{*}$ & $5.634^{*}$ & 0.252 \\
\hline
\end{tabular}

Legend: * The mean difference is significant at the 0.05 level

Thirteen years old girls were $3.75 \mathrm{~cm}$ taller than 12 years old, $10.74 \mathrm{~cm}$ than 11 years old, $15.92 \mathrm{~cm}$ than 10 years old, and $21.64 \mathrm{~cm}$ than 9 years old girls. Furthermore, 13 years old girls were $3.97 \mathrm{~kg}$ heavier than 12 years old $(\mathrm{p}=0.004)$, $11.83 \mathrm{~kg}$ than 11 years old ( $\mathrm{p}<0.001), 14.60 \mathrm{~kg}$ than 10 years old $(\mathrm{p}<0.001)$, and $19.28 \mathrm{~kg}$ than 9 years old $(\mathrm{p}<0.001)$. Only 11 years old girls did not significantly differ from 10 years old ( $\mathrm{md}=2.77 \mathrm{~kg}, \mathrm{p}=0.075)$. However, significant differences in BMI for 13-year group were found with 11-year $(\mathrm{md}=2.18$ $\left.\mathrm{kg} / \mathrm{m}^{2}, \mathrm{p}<0.001\right), 10$-year $\left(\mathrm{md}=2.20 \mathrm{~kg} / \mathrm{m}^{2}, \mathrm{p}<0.001\right)$ and 9-year group $\left(\mathrm{md}=3.02 \mathrm{~kg} / \mathrm{m}^{2}, \mathrm{p}<0.001\right)$, but without significant differences with 12-year group $\left(\mathrm{md}=0.57 \mathrm{~kg} / \mathrm{m}^{2}\right.$, $\mathrm{p}=1.00$ ). Significant differences were not found between 11 , 10 and 9 -year group of girls. On the other side, Bonferroni post-hock test showed statistically significant $(\mathrm{p}<0.05)$ differences between all age groups in boys in $\mathrm{BH}$ and $\mathrm{BM}$ variables (Table 4). Thirteen years old boys were $7.64 \mathrm{~cm}$ taller than 12 years old, $15.17 \mathrm{~cm}$ than 11 years old, 19.61 $\mathrm{cm}$ then 10 years old, and $23.98 \mathrm{~cm}$ than 9 years old boys. A gradual increase in $\mathrm{BH}$ was followed by the same trend $(\mathrm{p}<0.05)$ in $\mathrm{BM}$, whereby 13 years old boys were $5.63 \mathrm{~kg}$ than 12 years old, $12.64 \mathrm{~kg}$ than 11 years old, $16.26 \mathrm{~kg}$ than 10 years old, and $20.63 \mathrm{~kg}$ than 9 years old boys. In case of BMI 13-years old boys had significantly higher BMI than 10 years old $(p=0.001)$, and 9 years old $(p<0.001)$, but without significant differences compared to 12 years old $(\mathrm{p}=1.00)$, and 11 years old boys $(\mathrm{p}=0.069)$. Through the text were emphasized just the most relevant data, but for details about multiple comparisons consult Table 4 . 


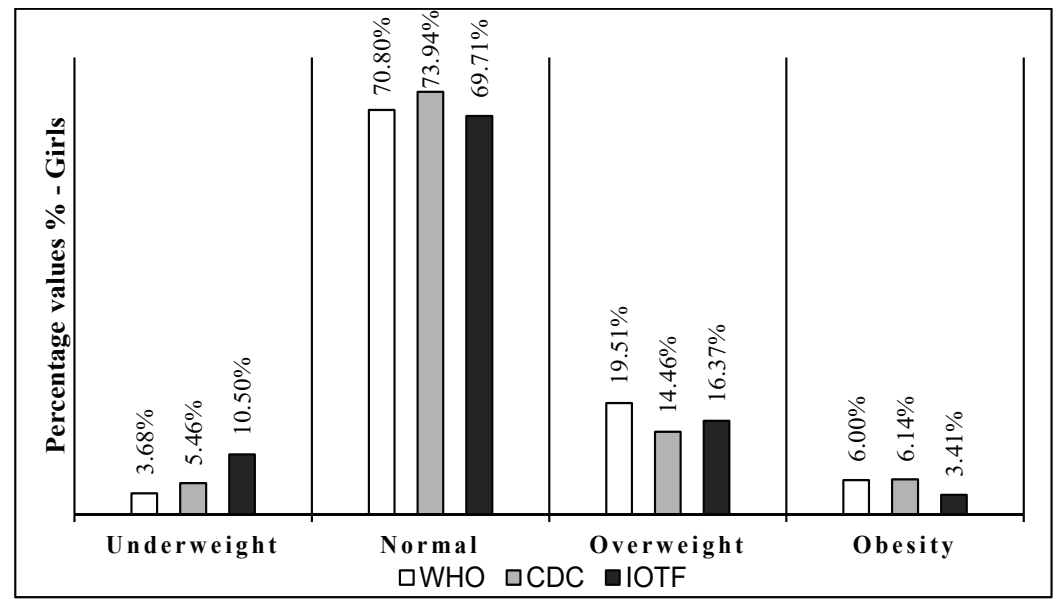

Figure 1. Nutritional status according to different references (WHO, CDC and IOTF) for Girls (9-13 yr.)

The results of relative prevalence of nutritional status and IOTF is presented graphically for girls (Figure 1) and in particular categories (Table 1) according to WHO, CDC boys (Figure 2).

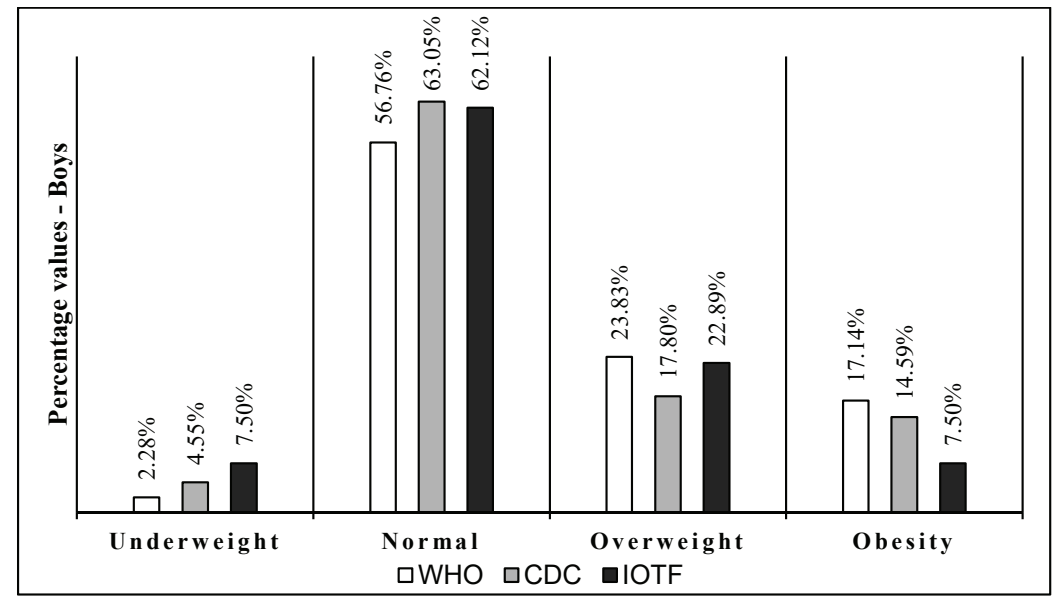

Figure 2. Nutritional status according to different references (WHO, CDC and IOTF) for Boys (9-13 yr.)

According to $\mathrm{WHO}$, prevalence of underweight was lower than in CDC and IOTF and higher in overweight regardless of gender, while according to CDC, prevalence of normal was higher comparing to WHO and IOTF but the lowest in overweight category in both, boys and girls. Pre- valence of underweight was the highest according to IOTF, with prevalence of obese being the lowest in girls as well as in boys. It seems that there was no specific trend of changes in prevalence of nutritional status relative to age (Table 5).

Table 5. Nutritional status according to different references (WHO, CDC and IOTF) and related to age and sex

\begin{tabular}{|c|c|c|c|c|c|c|c|c|c|c|c|c|}
\hline & \multirow{2}{*}{ Age } & \multicolumn{5}{|c|}{ Girls } & \multicolumn{5}{|c|}{ Boys } & \multirow{2}{*}{ Total } \\
\hline & & 9 & 10 & 11 & 12 & 13 & 9 & 10 & 11 & 12 & 13 & \\
\hline \multirow{4}{*}{$\begin{array}{c}\text { WHO } \\
(\%)\end{array}$} & Underweight & 5.26 & 3.03 & 4.49 & 1.44 & 2.86 & 6.08 & 1.15 & 0.74 & 1.35 & 2.11 & 2.97 \\
\hline & Normal & 69.17 & 67.88 & 75.64 & 69.06 & 72.14 & 52.70 & 59.20 & 56.30 & 56.08 & 59.15 & 63.72 \\
\hline & Overweight & 17.29 & 22.42 & 15.38 & 23.02 & 19.29 & 21.62 & 18.97 & 25.19 & 28.38 & 26.06 & 21.69 \\
\hline & Obesity & 8.27 & 6.67 & 3.21 & 6.47 & 5.71 & 19.59 & 20.69 & 17.78 & 14.19 & 12.68 & 11.62 \\
\hline \multirow{4}{*}{$\begin{array}{c}\text { CDC } \\
(\%)\end{array}$} & Underweight & 8.27 & 6.06 & 7.69 & 3.60 & 5.00 & 7.43 & 3.45 & 4.44 & 2.70 & 4.93 & 5.34 \\
\hline & Normal & 69.17 & 72.73 & 79.49 & 71.94 & 75.71 & 60.14 & 64.94 & 62.96 & 61.49 & 65.49 & 68.45 \\
\hline & Overweight & 16.54 & 14.55 & 10.26 & 17.99 & 13.57 & 17.57 & 14.37 & 16.30 & 23.65 & 17.61 & 16.15 \\
\hline & Obesity & 6.02 & 6.67 & 2.56 & 6.47 & 5.71 & 14.86 & 17.24 & 16.30 & 12.16 & 11.97 & 10.07 \\
\hline \multirow{4}{*}{$\begin{array}{l}\text { IOTF } \\
(\%)\end{array}$} & Underweight & 13.53 & 9.70 & 11.54 & 7.91 & 10.00 & 10.14 & 7.47 & 7.41 & 5.41 & 7.04 & 8.99 \\
\hline & Normal & 63.91 & 69.09 & 75.64 & 67.63 & 71.43 & 59.46 & 62.07 & 62.96 & 62.16 & 64.08 & 65.88 \\
\hline & Overweight & 18.05 & 18.18 & 12.18 & 19.42 & 14.29 & 22.30 & 21.26 & 20.74 & 25.00 & 25.35 & 19.66 \\
\hline & Obesity & 4.51 & 3.03 & 0.64 & 5.04 & 4.29 & 8.11 & 9.20 & 8.89 & 7.43 & 3.52 & 5.47 \\
\hline
\end{tabular}




\section{Discussion}

This study evaluated the nutritional status of children in Montenegro through three different references. They all differ in the results related to prevalence by defined categories in a more or lesser extent (Figure 1 and 2, and Table 3), which is similar to results from previous studies (Shan et al., 2010; Wang \& Chen, 2012; Martinovic et al., 2015; Jaksic et al., 2017). Following only BMI values relative to any of used references showed inconsistency but when BMI results were consolidated with age and gender-related differences in $\mathrm{BH}$ and $\mathrm{BM}$, it indicated that BMI may vary due to the laws related to growth and maturation of boys and girls. In that regards, the question of applicability and reliability, and which reference is the most suitable for the school population in Montenegro needs a further research, including another measures of body composition, such as body fat, waist circumference, waist to height ratio, muscle mass (Sharma, Metzger, Daymont, Hadjiyannakis, \& Rodd 2015; Schroder et al., 2014). The reasons for this could lie in a specificity of morphology related to geographical position and genetic heritage in Montenegro (Grasgruber et al., 2017). Therefore, IOTF reference seems as the most appropriate method because it bears more biological meaning comparing to distribution-based CDC and WHO references (Wang \& Chan, 2012; Cole, Bellizzi, Flegal, \& Dietz, 2000).

Three used reference values were constructed on samples before the global epidemic of obesity, while WHO and CDC references included only North America (Wang \& Chen, 2012). In contrast, IOTF references included the population from different regions in the world (Brazil, Great Britain, Netherlands, Hong Kong, Singapore and United States) and was based on sex-age-specific BMI values obtained at 18 years. Although analyzed many countries, study of Cole et al. (2000) did not include Eastern Europe (especially Dinaric Alps) which was shown to be different in physical stature (Grasgruber et al., 2017). The information obtained in this study are certainly useful, informative and relevant for comparison with global trends in nutritional status. However, developing a national growth-age-sex-stature independent indicator of nutritional status such as waist-to-height ratio would probably be the best way for the future monitoring and prevention of negative trends in nutritional status of schoolchildren in Montenegro.

Considering the prevalence defined by nutritional categories, the differences were present in relation to both, gender and age. According to all three used references (WHO, CDC and IOTF) prevalence of overweight and obesity was higher among boys than among girls, whereby WHO overestimated number of overweight and obese in both groups, followed by CDC and IOTF (see Figures 1 and 2). Conversely, WHO underestimated the number of underweight children in both gender groups and all age groups, followed again by CDC and then IOTF (See Figures 1 and 2). This additionally suggest that IOTF as a sex-age-specific reference may be more accurate than other two used in this study. In terms of overweight and obesity, the situation is alarming, because boys were more overweight and obese than girls of same age and in total, which supports the findings of Martinovic et al. (2015). On the other side, a comprehensive study from $\mathrm{Ng}$ et al. (2014), which showed that prevalence of overweight and obese children in Montenegro were $26.3 \%$ and $9.4 \%$, for boys and $27.3 \%$ and $8.3 \%$ for girls does not support the findings of the present study. The reason for concern may be raised because present study showed increase in number of obese boys comparing to prevalence of obesity from $\mathrm{Ng}$ et al. (2014), in each of used references as well as a big disbalance comparing to girls. Prevalence results from Martinovic et al. (2015) further support this notation because they used the same methodology as in the present study but the prevalence of obese was lower. In the short period of time (5 years) prevalence of overweight and obese boys increased in all three references: according to WHO criteria number of overweight and obese is increased by $8.7 \%$, according to CDC for $3 \%$, and according to IOTF for $3.9 \%$. A small increase in prevalence of overweight and obese of $3.9 \%$ by WHO criteria, $1 \%$ by CDC, and $0.7 \%$ by IOTF could be also noticed among girls.

It could be concluded that the increase in boys was relatively high considering the time frame, while increase in girls was somewhat smaller, but nevertheless present. In total prevalence of overweight and obese among Montenegrin children increased according to all three used methods, among which the biggest increase occurred according to WHO reference (6.3\%), followed by IOTF (2.2\%), and CDC (1.7\%). Roughly speaking, of 100 children, 6 would be underweight, 61 would be normal weight, and 33 would be overweight or obese. In other words, every third (WHO) or every fourth (CDC and IOTF) child in Montenegro aged 9-13 years is either overweight or obese.

\section{Acknowledgements}

There are no acknowledgements.

\section{Conflict of Interest}

The authors declare that there are no conflicts of interest.

Received: 10 September 2018 | Accepted: 21 November 2018 | Published: 01 February 2019

\section{References}

Bjelica, D. (2006). Sportski trening. Podgorica: Crnogorska sportska akademija.

Bjelica, D. (2010). Teorija sportskog treninga. Podgorica: Univerzitet Crne Gore.

Canadian Pediatric Endocrine Group (2018). Growth-Z software (current version 2018/05/22), a Microsoft ${ }^{\oplus}$ Excel workbook-based program that can do batch calculations for WHO and CDC parameters. From website: http://www.bcchildrens.ca/health-professionals/clinical-resources/endocrinology-diabetes/tools-calculators\#Anthro--calculators

Christie, B. (2000). Doctors revise declaration of Helsinki. British Medical Journal, 321(7266), 913.

Cole, T.J., \& Green, P.J. (1992). Smoothing reference centile curves: the LMS method and penalized likelihood. Statistics in medicine, 11(10), 13051319.

Cole, T.J., Bellizzi, M.C., Flegal, K.M., \& Dietz, W.H. (2000). Establishing a standard definition for child overweight and obesity worldwide: international survey. British Medical Journal, 320(7244), 1240.

Cole, T.J., Flegal, K.M., Nicholls, D., \& Jackson, A.A. (2007). Body mass index cut offs to define thinness in children and adolescents: international survey. British Medical Journal, 335(7612), 194.

de Onis, M.D., Onyango, A.W., Borghi, E., Siyam, A., Nishida, C., \& Siekmann, J. (2007). Development of a WHO growth reference for school-aged children and adolescents. Bulletin of the World health Organization, 85, 660-667.

Grasgruber, P., Popovic, S., Bokuvka, D., Davidovic, I., Hrebickova, S., Ingrova, P., Potpara, P., Prce, S. \& Stracarova, N. (2017). The mountains of giants: an anthropometric survey of male youths in Bosnia and Herzegovina. Royal Society Open Science, 4(4), 161054.

Jaksic, M., Martinovic, M., Belojevic, G., Kavaric, N., Asanin, B., Samardzic, M., Pantovic, S., \& Boljevic, J. (2017). Prevalence of and contributing factors to overweight and obesity among the schoolchildren of Podgorica, Montenegro. Srp Arh Celok Lek, 145(1-2), 20-5.

Kuczmarski, R.J., Ogden, C.L., Guo, S.S., Grummer-Strawn, L.M., Flegal, K.M., Mei, Z., Wei, R., Curtin, L.R., Roche, A.F., \& Johnson, C.L. (2002). CDC growth charts for the US: methods and development. Vital Health Stat, 11(246), 1-190. 
LMS growth software (current version 2.77, 2012), a Microsoft add-in to access growth references based on the LMS method. British Medical Council. From website: http://www.healthforallchildren.com/shopbase/shop/software/Imsgrowth/

Lukaski, H. (Ed.) (2017). Body Composition. Boca Raton: CRC Press.

Martinovic, M., Belojevic, G., Evans, G.W., Lausevic, D., Asanin, B., Samardzic, M., Terzic, N., Pantovic, S., Jaksic, M., \& Boljevic, J. (2015). Prevalence of and contributing factors for overweight and obesity among Montenegrin schoolchildren. The European Journal of Public Health, 25(5), 833839.

Ng, M., Fleming, T., Robinson, M., Thomson, B., Graetz, N., et al. (2014). Global, regional, and national prevalence of overweight and obesity in children and adults during 1980-2013: a systematic analysis for the Global Burden of Disease Study 2013. The lancet, 384(9945), 766-781.

Popkin, B.M. (2006). Global nutrition dynamics: the world is shifting rapidly toward a diet linked with noncommunicable diseases. The American Journal of Clinical Nutrition, 84(2), 289-298.

Research Brief: "European Initiative for the Monitoring of Obesity of Children" (25.5.2016). Podgorica: Institute of Public Health. Set 25.5.2016 from the website: http://www.ijzcg.me/2016/05/obavjestenje-o-istrazivanju-evropska-inicijativa-pracenja-gojaznosti-djece/

Schroder, H., Ribas, L., Koebnick, C., Funtikova, A., Gomez, S.F., Fito, M., Perez-Rodrigo, C., \& Serra-Majem, L. (2014). Prevalence of abdominal obesity in Spanish children and adolescents. Do we need waist circumference measurements in pediatric practice? PLoS One, 9(1), e87549.
Shan, X.Y., Xi, B., Cheng, H., Hou, D.Q., Wang, Y., \& Mi, J. (2010). Prevalence and behavioral risk factors of overweight and obesity among children aged 2-18 in Beijing, China. International Journal of Pediatric Obesity, 5(5), 383-389.

Sharma, A.K., Metzger, D.L., Daymont, C., Hadjiyannakis, S., \& Rodd, C.J. (2015). LMS tables for waist-circumference and waist-height ratio Z-scores in children aged 5-19y in NHANES III: association with cardio-metabolic risks. Pediatric Research, 78(6), 723-729.

Tambalis, K.D., Panagiotakos, D.B., Arnaoutis, G., Psarra, G., Maraki, M., Mourtakos, S., Grigorakis, D., \& Sidossis, L.S. (2015). Establishing cross-sectional curves for height, weight, body mass index and waist circumference for 4 to 18 years old Greek children, using the Lambda Mu and Sigma (LMS) statistical method. Hippokratia, 19(3), 239-248.

Tuan, N.T., \& Nicklas, T.A. (2009). Age, sex and ethnic differences in the prevalence of underweight and overweight, defined by using the CDC and IOTF cut points in Asian children. European Journal of Clinical Nutrition, 63(11), 1305.

Wang, Y., \& Chen, H.J. (2012). Use of percentiles and z-scores in anthropometry. In Handbook of anthropometry (pp. 29-48). Springer, New York, NY. World Health Organization (1995). Physical status: the use and interpretation of anthropometry. Report of a WHO Expert Committee. World Health Organ Tech Rep Ser. Geneva.

World Health Organization (2000). Obesity. Preventing and managing the global epidemic: report of a WHO consultation on obesity. WHO Technical Report Series, No. 894, WHO: Geneva. 